\title{
Perceptions of Corruption, Political Distrust, and the Weakening of Climate Policy
}

\author{
Ryan Rafaty*
}

\begin{abstract}
This article presents a theory of the relationship between public perceptions of political corruption and the strength of national climate change mitigation policies, which is then formally tested in a time-series-cross-section analysis of twenty industrialized democracies from 1990 to 2012. The analysis reveals that greater perceptions of corruption are highly and robustly associated with weaker climate policies-especially nonmarket policies-when controlling for relevant political and economic variables. A government perceived by citizens to be "mildly corrupt" but that transitions to "very clean" would be associated with strengthening nonmarket climate policies from levels in Greece to levels in Sweden or from levels in Poland to those in Denmark. Lax market-based climate policies are also significantly linked to greater perceived corruption, but notably, they are robustly associated with the size of domestic energy-intensive, trade-exposed industries, which have received substantial environmental tax exemptions and free allocations even in the greenest, high-trust, low-corruption democracies.
\end{abstract}

National policies designed to mitigate the risks of climate change have proliferated from under ten worldwide in the early 1990s to more than 1,200 today (Nachmany et al. 2017). However, their stringency has varied starkly both crossnationally and over time, with current intended nationally determined contributions (INDCs) under the Paris Agreement, including those of industrialized nations, deemed wholly insufficient to limit the rise in global mean temperature to well below 2 degrees Celsius (Rogelj et al. 2016; Victor et al. 2017). In many jurisdictions, climate policy frameworks have remained either lax or nonexistent, as with the roughly three-quarters of global greenhouse gas emissions that remain unpriced and the roughly 45 percent of global emissions that remain unregulated by any policy at all under current INDCs (World Bank et al. 2017). Few jurisdictions have managed to cumulatively, without disruption or backsliding, increase the stringency of emissions abatement policies

* I thank Mette Eilstrup-Sangiovanni, Joanna Depledge, Detlef Jahn, David Runciman, Thomas Ferguson, Michael Grubb, Geoffroy Dolphin, John Dunn, and three anonymous reviewers for valuable comments and suggestions at various stages in the writing process. 
since the 1990s. These realities cast reasonable doubt on the prospects for compliance with Articles 4.3 and 4.9 of the Paris Agreement, informally known as the "ratchet mechanism," which stipulate that parties to the agreement must every five years present domestic mitigation plans that exceed prior commitments and ambitions (United Nations Framework Convention on Climate Change 2015).

Understanding the necessary or sufficient political conditions for ratcheting up national climate policies is now vital to global mitigation efforts. This article's core contribution is to present a theory and empirical evidence strongly suggesting that public perceptions of institutional corruption, and political distrust more generally, should become central to the analysis of climate policy constraints.

Current challenges to mitigation policy have coincided with a "global implosion of trust," with 2017 marking the largest-ever recorded rise in public distrust of government, business, media, and NGOs (Edelman 2017). Public perceptions of corruption have risen across numerous countries surveyed, including many industrialized democracies (Transparency International 2017). Claims of political corruption are "prone to moralism" and disputes over definition (Nye 1967), and in particular, claims of corruption within developed democracies have sometimes been dismissed by social scientists as sententious hyperbole. But in recent decades, research interest in corruption has surged, evident in the twentyfold increase in the number of social science articles published with the words "political corruption" in the title from 1992 to 2014 (Rothstein and Varraich 2017, 7). Although corruption has been directly linked to a plethora of public policy failings-lower life expectancy, lower life satisfaction, less provision of education and health care, lower levels of investment and economic growth, and greater income inequality and poverty (Gupta et al. 2002; Holmberg and Rothstein 2011; Mauro 1995) —scholarship on its impact upon environmental protection, particularly in industrialized democracies, is still in its early stages (Fredriksson and Mani 2002; Fredriksson and Neumayer 2016; Pellegrini and Gerlagh 2006). Most quantitative, macro-comparative assessments of national climate policies have excluded variables related to political corruption or distrust (Bättig and Bernauer 2009; Bernauer and Böhmelt 2013; Jahn 2016; Neumayer 2003; Scruggs 2003; Steves and Teytelboym 2013). But recent events, such as the US withdrawal from the Paris Agreement and the Trump administration's dismantling of Obama-era climate regulations after a polarized and scandal-focused 2016 presidential election, pressures on climate policy in the UK after a distrust-driven Brexit referendum campaign, and the resurgence of deforestation in Brazil amid successive corruption scandals, all indicate that crises of confidence in government-with their attendant distractions, malfeasances, and short-termism-may be a decisive factor derailing stringent and foresighted climate policy making.

Has the project of ratcheting up climate policies fallen victim to collateral damage from public perceptions of corruption and political distrust? Or does 
this hypothesis carry little explanatory weight when controlling for other common explanations, such as government ideology on the left-right spectrum or the political influence of carbon-intensive industry? Might the answer depend on the type of climate policy?

To test this hypothesis at a more systematic level, this article adopts a definition of institutional corruption that is measurable based on longitudinal survey data and presents a theory of its corrosive impact on climate policies in industrialized democracies. After detailing the causal mechanisms and assumptions underpinning the analysis, the theory is then formally tested with a time-series-cross-section (TSCS) analysis, with results presented on the effects of perceived corruption on market-based and nonmarket climate policy stringency in twenty industrialized democracies from 1990 to 2012. The analysis utilizes data from the most conceptually rigorous measure of policy stringency currently available, the OECD's Environmental Policy Stringency index, which enables the disaggregation of market-based and nonmarket policies.

The results reveal, as predicted, that nonmarket climate policies are significantly weakened by public perceptions of institutional corruption, when controlling for relevant political and economic factors. Lax market-based policies are also robustly associated with perceived corruption but are notably more sensitive than nonmarket policies to the presence of sizable domestic energyintensive, trade-exposed industries. The article concludes with a recapitulation of the theory and main findings as well as a brief reflection on policy implications.

\section{Theory and Approach}

This study adopts a conception of "institutional corruption" that combines insights from the work of Heidenheimer (2002) and Lessig $(2011,2013){ }^{1}$

Institutional corruption is present "when there is a systemic and strategic influence which is legal, or even currently ethical, that undermines the institution's effectiveness by diverting it from its purpose or weakening its ability to achieve its purpose, including, to the extent relevant to its purpose, weakening either the public's trust in that institution or the institution's inherent trustworthiness" (Lessig 2013, 553, emphasis added). The definition is consequentialist; its benchmark is the negative impact of systemic, undue influences upon institutional performance; it does not purport to predetermine the institution's purpose. Indeed, a legislature has an abundance of purposes in different contexts, from ensuring adequate financial regulation to providing funding for basic public services. But in the particular context of global climate change and "nationally determined contributions" to mitigation under the United Nations Framework

1. The conception of corruption adopted herein neither makes any virtue-focused claims about broader political decay or degeneracy (as was common in political thought prior to the eighteenth century; see Buchan and Hill 2014) nor narrowly focuses on illicit private-regarding acts of individual politicians (as is common in the modern, legalistic conception; see Nye 1967). 
Convention on Climate Change (UNFCCC), a nation's self-declared and widely agreed upon purpose is to gradually strengthen policies that mitigate climatic risks at a socioeconomically acceptable cost, and this purpose is to be carried out primarily through national legislatures. This entails government responsiveness not exclusively to the narrow strategic interests of carbon-intensive industries but also to broader public interests and international commitments.

Institutional corruption may take the form of money in politics, which in certain countries has systemically and unduly influenced policy priorities and even election outcomes (Bekkouche and Cagé 2018; Ferguson 1995; Ferguson et al. 2018; Lessig 2011; Winters and Page 2009). The striking, well-supported findings of Gilens and Page (2014) regarding the inordinately elite-driven and oligarchic nature of policy making in the US Congress, for example, suggest something contrary to beneficent lobbying. They reveal prolonged, multidecadal nonresponsiveness of government to citizens' preferences; their results further imply that even if the majority of citizens wanted stringent policies to reduce greenhouse gas emissions, such policies would not come to fruition without the political and financial backing of substantial swaths of economic elites and big business. Indeed, Lessig $(2011,59)$ claims that the improper institutional dependence of lawmakers upon moneyed interests has been the decisive cause of protracted climate policy inaction in the US, citing figures that carbon-intensive business interests spent US\$210.6 million in 2009 to successfully veto national cap-and-trade legislation, nearly ten times the amount spent by green and other pro-reform groups.

But institutional corruption may also take other forms, such as ideologyfor example, an unyielding laissez-faire prejudice against government "interference" that becomes a self-fulfilling prophecy of government decay and ineffectiveness, or an eschatological belief that the end of the world is near and therefore mitigating ecological threats is in vain. Such ideology among legislators would be antithetical to good governance and divert a legislature from its purposes. Institutional corruption may also be exacerbated by factious and scurrilous media representations of government incompetence and scientific uncertainty about climatic risks, to the extent that such representations inflame distrust and cynicism about the political motives of lawmakers and scientists, further reinforcing legislative inaction (Runciman 2017).

The critical question is how to measure and operationalize institutional corruption, given that it may take multiple forms. I have adopted an approach that focuses on public opinion, that is, public perceptions of corruption. There are numerous justifications for this choice. First, this study focuses on industrialized democracies wherein, even when pretensions to democracy may be tawdry and policy outcomes responsive to public concerns are far from guaranteed, citizens retain (on notionally equal terms) the right and responsibility to judge and decide how sovereignty is to be exercised (Dunn 2014, 20). In a democracy, therefore, political activity may be deemed corrupt when it is determined so in the court of broad public opinion. But there are gradations. When 
both the broad public and elected officials agree that certain activity is offensive to the norms of democracy and deserving of reform or retribution, corruption is unambiguous (i.e., "black corruption," according to Heidenheimer's 2002, 152-154, typology). At the other extreme, the majority of both citizens and elected officials may consider certain forms of corruption to be tactless but nevertheless petty and unworthy of sanction (i.e., "white corruption"). In between these two extremes are forms of "gray corruption," whereby the broad public deems certain activity to be corrupt while the bulk of the professional political class is indifferent to the supposed indiscretion and declaim against any such accusation. It is in the middle of the corruption spectrum-the ambiguous gray area where public and elite opinions are divided-where forms of political corruption "are the most difficult to define and detect, and consequently are potentially most destructive to a political system organized along democratic principles" (Peters and Welch 1978, 975). Institutional corruption may take any of these three forms, but it is clear that focusing on public perceptions is the optimal empirical approach, especially in detecting gray areas of corruption.

Another reason to focus on public perceptions is that robust and crossnationally comparable measures of particular forms of institutional corruption, such as money in politics, are notoriously difficult to attain, particularly in longitudinal format. On the other hand, national survey evidence detailing levels of perceived corruption are available in comparable, annual format from numerous high-quality sources (Standaert 2015; Transparency International 2017).

It is of course hard to know definitively whether perceptions of corruption are indicative of protracted institutional corruption or are more fleeting reactions to individual political scandals, for example, the Christian Democratic Union's campaign finance scandal in Germany, the parliamentary expenses scandal in the UK, the Marbella property scandal in Spain, or the cacophony of scandals currently enveloping the Trump administration. Such scandals have certainly reinforced public perceptions of elite misbehavior and nonresponsiveness, but if such public sentiments persist over time, they are very likely indicative of a more systems-based, institutional corruption (in Lessig's 2011 rendering) rather than fleeting cases of individual corrupt acts (in Nye's 1967 rendering). And indeed, the Bayesian Corruption Index and Corruption Perceptions Index, detailed in the next section and graphed in Figure 1, vary considerably across industrialized democracies while showing fairly stable within-country perceptions over time, with a slight upward trend since 2005. This strongly suggests that perceptions of corruption are a reliable proxy for the baseline level of institutional corruption, particularly the "gray" areas where public and elite opinions may be divided.

Perceived corruption can be understood as an autocatalytic political phenomenon. In the first instance, perceived corruption is a symptom of underlying institutional malfunction or exclusive legislative responsiveness to organized economic elites, business interests, or ideological factions. But if left unchecked, 

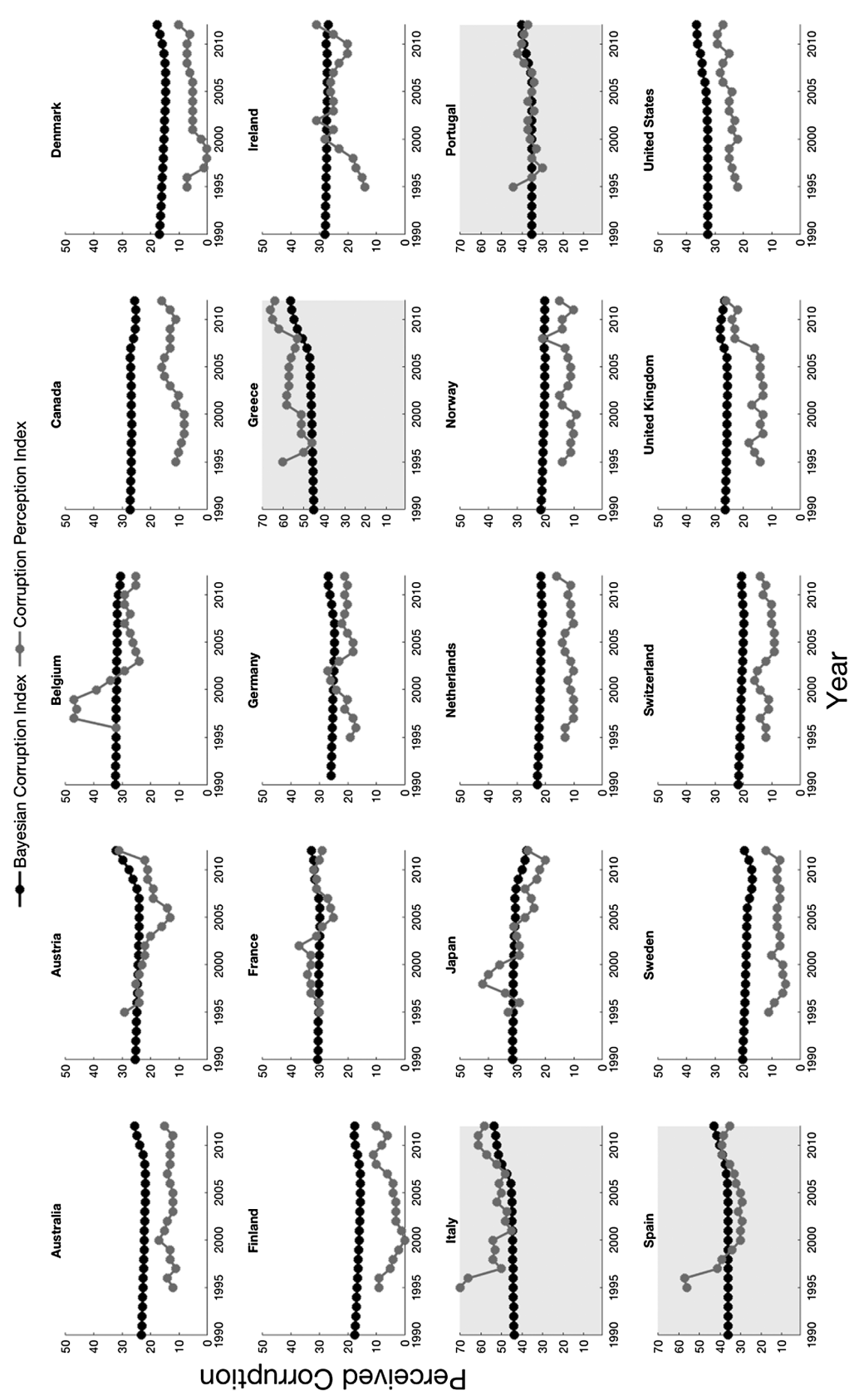

苛

종

in

苛

矛

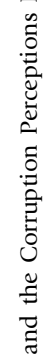

곯

คั ฮ

๖े

莺

ช 0 噉

ठ స్․

글

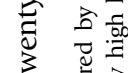

(3)

$\Xi \quad$ 过

으 응

产 总

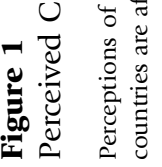


it may also become a cause of further civic and political putrefaction, whereby distrust distracts from long-term policy making and reinforces further government partiality, regulatory inaction, and nonresponsiveness.

The causal role of perceptions is particularly pertinent in the domain of climate policy. In democracies where a broad segment of the population perceives institutional corruption, a politics of resignation may set in, whereby mass-based interest groups that might otherwise become organized and campaign for greater action on environmental issues are rendered impotent by diminished expectations. At the same time, among citizens who are not particularly concerned about climate change, perceived corruption may reinforce their insouciance. The perception may have this effect by breeding distrust of politicians and cynicism about their motives, inflaming preexisting antipathies to taxes and "big government," and reinforcing beliefs in the logic of laissez-faire (Persily and Lammie 2004). Under such regimes, democratic politicians may neglect to pass stringent cost-imposing climate policies, insofar as doing so may elicit electoral backlash from both a distrustful public and native carbon-intensive industries (Jenkins 2014).

Numerous case studies corroborate these hypotheses. In Australia, the former prime minister, Kevin Rudd, has blamed his failed reelection partly on the passage of an unpopular carbon tax (Rootes 2014). A crisis of confidence in the Australian government was a major culprit; a media campaign, promoted by the native mining industry, was waged to cast aspersions on the government's alleged incompetence in raising energy prices and benefiting certain native (clean energy) companies at the expense of others crucial to national income (energy-intensive mining and manufacturing) (Eckersley 2013). Perceived corruption also bolstered distrust in Spanish and Portuguese political institutions in 2011-2012, with subsequent setbacks to climate policy; panel survey evidence suggests that rising distrust had little to do with the financial crisis but rather with the widespread perception among citizens "that representative institutions are not responsive to their demands and concerns," exacerbated in Portugal by "elite misbehavior" (Torcal 2014, 19). To the contrary, in Scandinavian countries, sustained public trust in noncorrupt political institutions has been a primary enabler of early and sustained support for $\mathrm{CO}_{2}$ taxation (Andersen 2004; Hammar and Jagers 2006).

By focusing on the effect of perceived corruption on the climate policies of industrialized democracies, this article contributes to previous scholarship that has mostly conceived of corruption in its ostensibly more extreme forms (i.e., illicit, quid pro quo, "black" corruption) and has tended to conflate the impacts in democracies and autocracies. The theory herein contains four related assumptions:

1. Institutional corruption, where it is manifest, yields a significant negative effect on the strength of climate policies across industrialized democracies, when controlling for relevant political and economic factors. 
2. Perceptions of corruption may be taken as a reliable proxy for institutional corruption. Such perceptions are not exclusively or even primarily an outcome of fleeting individual corruption scandals but are commonly a symptom of an underlying institutional corruption to which all democracies are potentially vulnerable; however the instantiations and causal mechanisms of undue legislative influence may differ cross-nationally, public perceptions serve as an adequate proxy for these "gray areas" of corruption.

3. The perception of corruption may itself be an independent cause of weak climate policy, by contributing to a politics of resignation among groups of environmentally motivated citizens and a politics of distrust among environmentally indifferent citizens. Such perceptions are likely to bolster the strategic influence and laissez-faire demands of native energy-intensive industries opposed to climate regulations.

4. Institutional corruption is likely to negatively impact policy areas other than climate change, particularly areas that also involve vested business interests and require long-term foresight, planning, and coordination (e.g., regulating systemic risk to the banking sector). Perceptions of institutional corruption may be most pernicious in legislative domains where there is a significant time lag between the policies enacted and their intended outcomes. While the evidence in this study cannot confirm this cross-policy effect, social scientists ought to test this hypothesis elsewhere and identify the distinctive properties of perceived corruption in other relevant policy domains.

One proviso should be added: the predictions of voter resignation and distrust in assumption (3) are not deterministic but simply represent dominant psychological tendencies that arise with a long-term, collective action problem like climate change. It is perfectly feasible that perceived corruption may motivate a mass-based popular reform movement in certain countries. But it is also quite possible that the pernicious force of institutional corruption impedes such movements long enough to delay serious efforts to mitigate climate change not only over the past several decades but also in the years ahead.

\section{Operationalizing Corruption}

In the TSCS analysis, I have used the Bayesian Corruption Index (BCI) developed by Standaert (2015). The BCI combines measures of public perceptions of corruption from twenty widely used international surveys, including those of Transparency International, the Bertelsmann Transformation Index, Gallup World Poll, and the Economist Intelligence Unit. Using a Bayesian Gibbs sampler algorithm, the $\mathrm{BCI}$ is able to collate these surveys, deal with missing data while extending the time period covered, reduce measurement error, and produce smaller confidence intervals than those of widely used alternative measures, such as the Corruption Perceptions Index (CPI) and the World Governance Indicators (WGI) (Standaert 2015). Despite their methodological differences, the BCI has 
high overall correlations with the CPI (0.956) and WGI (0.948). The index is on a scale from 0 to 100 , with zero corresponding to absolutely no perceived corruption and higher values corresponding to greater corruption.

Figure 1 plots cross-national levels of perceived corruption based on both the BCI and, for comparison, the CPI (Transparency International 2017). The CPI, which has been converted so that higher values equal higher corruption, shows relatively greater interannual variation; the methodology used to compute the $\mathrm{BCI}$, on the other hand, assumes that much interannual variation across surveys is a product of measurement error, that perceived corruption is a matter of cumulative experience and partially a product of previous annual values, and that these multiple surveys and scores can be collated to arrive at more precise measurements (Standaert 2015). These assumptions are consistent with our focus on persistent institutional corruption rather than just fleeting political scandals. But to ensure that the results of the TSCS analysis are not biased by the choice of corruption metric, I also use the CPI in robustness tests of the model.

\section{Dependent Variable: The Environmental Policy Stringency Index}

To measure the strength of national climate policies, I have used the OECD's Environmental Policy Stringency (EPS) index as the dependent variable. The EPS index covers most OECD countries during the period 1990-2012.

The EPS index defines policy stringency as "a higher, explicit or implicit, cost of polluting or environmentally harmful behavior" (Botta and Koźluk $2014,14)$. The focus on stringency has the advantage of being directly observable and quantifiable. As the authors explain,

this is straightforward for instruments like taxes-where a higher price on a unit of pollutant implies higher stringency. Lower (stricter) emission limit values have a similar interpretation. For subsidizing instruments, such as feed-in tariffs or subsidies to $\mathrm{R} \mathrm{D}$, a higher subsidy is also interpreted as more stringent environmental policy-such subsidies increase the opportunity costs of polluting and can be assumed to be paid by the bulk of tax payers or consumers, hence providing an advantage to "cleaner" activity. (14)

The EPS index focuses on policies that mitigate greenhouse gas emissions and air pollutants, with a particular focus on the electricity sector, where there is the most low-hanging fruit in terms of emissions reduction potential. The index omits climate policies in the buildings, transport, and agricultural sectors but has the advantage for our purposes of narrowing in on the most prevalent and far-reaching market-based and nonmarket climate policies: greenhouse gas taxes, cap-and-trade, feed-in tariffs for the promotion of renewable energy, emission limits on power plants, and public expenditure on renewable energy. ${ }^{2}$

2. The EPS index does not include policies for all low-carbon technology types, such as nuclear and hydropower, "primarily due to the high complexity of the regulations" and related issues of 
Table 1

Components of the EPS Index

\begin{tabular}{lclc}
\hline Policy type & Weight & Indicator & Subweight \\
\hline Market-based policies & 0.5 & Taxes $\left(\mathrm{CO}_{2}, \mathrm{NO}_{x}, \mathrm{SO}_{x}\right.$, Diesel) & 0.166 \\
& & $\begin{array}{l}\text { Trading schemes }\left(\mathrm{CO}_{2} \text {, renewable energy }\right. \\
\text { certificates, energy efficiency certificates })\end{array}$ & 0.166 \\
& & Feed-in tariffs (solar, wind) & 0.166 \\
Nonmarket policies & $0.5 \quad$ & Standards (emission limit values for $\mathrm{NO}_{x \prime}$ & 0.25 \\
& $\mathrm{SO}_{x}$, and $\left.\mathrm{PM}_{x}\right)$ & 0.25 \\
& $\begin{array}{l}\text { Public } \mathrm{R} \& \mathrm{D} \text { subsidies and expenditure } \\
\text { on renewables }\end{array}$ & \\
\hline
\end{tabular}

Note. From Botta and Koźluk (2014). The index is on a scale ranging from 0 to 6, with higher values representing greater policy stringency.

Hence the index could also justifiably be called the "Climate Policy Stringency" index. Table 1 provides a breakdown of the policy components and weightings of the EPS index, and Figure 2 displays cross-national trends in market-based, nonmarket and overall policy stringency from 1990 to 2012.

Botta and Koźluk (2014, 6-7) emphasize that the EPS index should be understood as an imperfect simplification of policy stringency, given the inevitable difficulties involved: the multidimensionality of policies (e.g., the multitude of possible policies and design features); sampling (i.e., variation in the degree to which different firms, plants, and sectors are exposed to environmental taxes or regulations); and other related issues. Since policies vary along these multiple dimensions, practical choices have to be made about what aspects to include in the index. The authors of the EPS index have decided, for example, that the carbon tax indicator should focus on rates that apply to firms using large coal combustion plants to generate electricity. Ideally, they should use data on economy-wide, emissions-weighted carbon prices, which would include electricity and heating, industry, buildings, agriculture, and transport sectors. But given the current lack of longitudinal data of this sort, ${ }^{3}$ they have arguably made a sound decision; from a climate perspective, if firms using coal-powered electricity are exempt from a carbon tax, then the tax loses much of its efficacy and purpose. So Denmark receives a score of 0 on the carbon tax indicator, even though it was one of the first countries to implement the tax in 1992; this is

public safety (Botta and Koźluk 2014, 14-15). Here the authors emphasize that the index remains a proxy and cannot possibly cover all potentially relevant policies.

3. Currently available carbon price data from the OECD and World Bank are not standardized to be economy-wide and emissions weighted and are limited to only a few recent years. There are currently research efforts to remediate this (e.g., Dolphin et al. 2016), and future comparative studies should incorporate updated datasets. 

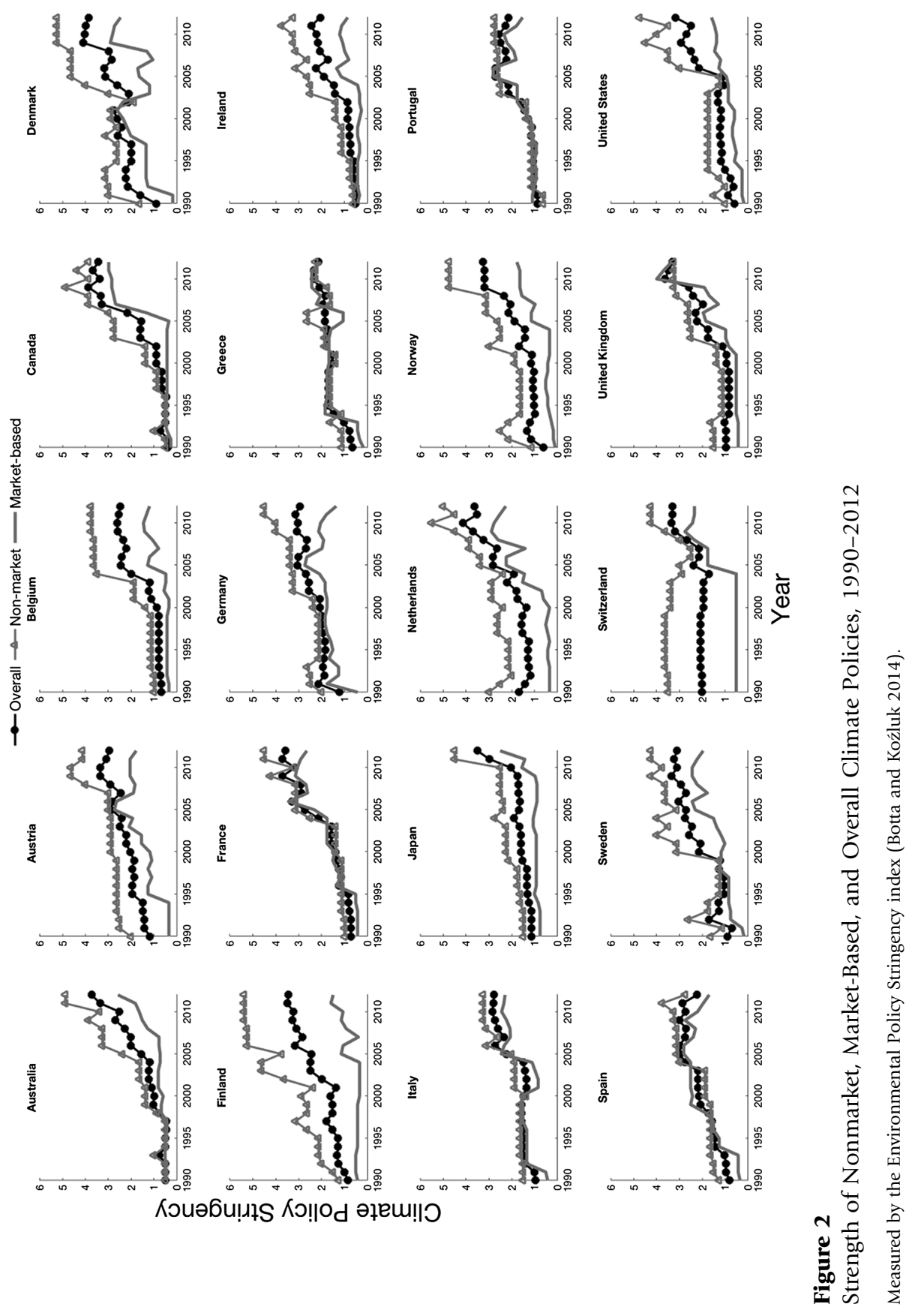
because the coal used to generate electricity for industry is exempt from the Danish carbon tax (as it is in many other countries) and because Danish firms that participate in the EU Emissions Trading System are entitled to a full refund of the carbon tax. This of course omits the fact that Denmark's carbon tax has applied to households and the service sector since the early 1990s. But the EPS index "tries to focus on the relative stringency faced by comparable firms across countries and does not provide an overall count of all environmental policy instruments introduced regardless of their coverage." ${ }^{4}$

The EPS index has the advantage not only of permitting longitudinal analysis of overall policy stringency but of enabling the disaggregation of market-based and nonmarket polices. I have therefore modeled nonmarket and market-based policies separately, in addition to overall policy stringency.

\section{Independent and Control Variables}

Numerous additional independent variables have been included in the model. In previous empirical studies, these variables have had a significant effect on climate policies or emissions during certain time periods, and here I treat them as control variables that are classified as either political or economic. Controlling for these variables in the TSCS model enables us to reliably determine whether perceived corruption exerts a significant net effect on the strength of climate policies.

The political control variables include the following:

1. Left-wing ideology in government. I assume that a greater degree of left-wing (and green) ideology of governing parties generally corresponds with greater environmental policy stringency (Jahn 2016; Neumayer 2003); here I use a left-right index arrived at through a deductive approach that systematically analyzes governing party manifestos for dominant ideological proclivities, as detailed by Jahn $(2011,2016)$. Higher values correspond to greater left-wing proclivities.

2. Corporatism. Characterized by a tripartite interest group structure-involving labor unions, peak industrial associations, and government-corporatism has been directly linked to stronger government performance on environmental outcomes during certain time periods (Scruggs 2003); here I use a time-varying index of corporatism, as developed and described by Jahn, with higher values corresponding to greater corporatism $(2014,2016)$.

3. Disproportional representation. Disproportionality-that is, the disparity between the number of votes parties receive and their acquired seats in parliamenttends to disadvantage green and other minority parties, reduce the likelihood of multiparty consensus-driven coalitions, and potentially increase the influence of organized special interests (Lijphart 2012; Moosbrugger 2012);

4. I thank Enrico Botta for clarifying this issue for me in an email conversation, from which the quotation is derived. 
here I use the disproportionality index developed by Gallagher (1991), which I have attained in updated TSCS format from the Comparative Political Dataset (Armingeon et al. 2014).

The economic control variables include the following:

1. GDP per capita in purchasing power parities. This variable accounts for the possibility that even among developed countries, constraints on national income may affect voters' and politicians' perceptions of the economic strain on the population from emissions limits; the data are obtained from the World Bank (2017).

2. The contribution to GDP from mining, manufacturing, and utilities. This measure accounts for the economic power of carbon-intensive sectors of the economy (fossil fuels, iron and steel, chemicals, cement, refined petroleum, etc.) and may serve as a proxy for the relative economic strain on native industries from regulations and limits on emissions (Grubb et al. 2014); the data are obtained from the United Nations (2017).

3. Openness to trade. This variable is measured as the sum of imports and exports divided by GDP. National economies with higher volumes of trade may have greater negative pressures on environmental policy due to competitiveness concerns (Damania et al. 2003); the data are obtained from the World Bank (2017).

4. The percentage contribution of hydro and nuclear energy to the electricity mix. Countries with preexisting low-carbon baseload power sources may have a greater proclivity to pass relatively stringent decarbonization policies, given the relative ease and low cost to the economy. This variable is computed based on data from the International Energy Agency (2017).

Due to a lack of comparable longitudinal data, I have omitted the variables of public concern about climate change and the strength of domestic green interest groups. However, no study hitherto has been able to rectify the lack of comparable longitudinal data on public concern about climate change (future work ought to as more survey evidence becomes available). Moreover, despite the lack of adequate cross-national data on the relative strength of green interest groups, I have used the control variable of left-right government ideology, which can be taken as an adequate proxy for the likely responsiveness of government to such interest groups.

\section{Case Selection}

This study focuses on twenty industrialized democracies. All have been classified as "Annex II" OECD countries under the UNFCCC since the 1990s, with 
elevated legal responsibility to reduce emissions both at home and abroad. ${ }^{5}$ To account for selection bias, it is important to consider why this particular choice of countries is warranted. The focus on developed economies is a limitation, given the global requirements of climate change mitigation; but in focusing on the richest democracies, there are numerous advantages beyond the fact that there is more plentiful and reliable political, economic, and policy-related data for OECD countries.

For purposes of retrospective analysis, the fact that Annex II OECD countries have from the beginning of the UNFCCC borne the bulk of the legal responsibility to reduce emissions is significant. It is among these countries that the most stringent climate policies are likely to be identified. Where differences in capabilities do exist among these rich countries, they are fundamentally due to sociopolitical or structural reasons rather than administrative, technological, financial, or developmental barriers. For this reason, they are particularly well suited for comparative political analysis. There are also many compelling normative reasons to expect the bulk of the first-mover response to climate change to come from the most economically developed countries, which have been responsible for the vast majority of global cumulative emissions since the late nineteenth century (Caney 2010).

\section{Model Specification}

Before addressing the results, a few key points about the econometric method should be made. The model is computed using Prais-Winsten (OLS) estimation with panel-corrected standard errors and an AR(1) autocorrelation structure, as described and recommended by Beck and Katz (1995). Country and year dummies are included on the right side of the equation to account for countryspecific and time-specific effects. Given that there are twenty countries across twenty-two years, the Prais-Winsten estimator is more appropriate than most other estimators originally designed for micropanels (i.e., short periods typically of $T<5$ and a substantial number of units, with asymptotics of $N \rightarrow \infty$ ). The computed panel-corrected standard errors are robust to heteroskedasticity, serial correlation, and cross-sectional dependence, which are present in the data. ${ }^{6} \mathrm{~A}$ test of overidentifying (orthogonality) conditions confirms that a random effects model is inconsistent with the data and that fixed effects is indeed more appropriate. ${ }^{7}$ Unit-root tests deliver mixed results, raising the question of whether some

5. There are in fact a total of twenty-three Annex II OECD countries under the UNFCCC's classification system. This study focuses on twenty of them-excluding Iceland, Luxembourg, and New Zealand-due to missing data on the dependent variable.

6. The likelihood-ratio test and Wooldridge test each confirmed the presence of heteroskedasticity and serial correlation, respectively. The Breusch-Pagan Lagrange multiplier independence test confirmed the presence of cross-sectional dependence.

7. Unlike the standard Hausman test, this test (performed using "xtoverid" in STATA) is robust to heteroskedasticity. 
of the data are actually nonstationary. ${ }^{8}$ But as Beck and Katz (2011) suggest, it is theoretically implausible that the kinds of political economy variables used herein (e.g., indices of policy strength, left-wing government ideology, and corporatism, or manufacturing as a percentage of GDP) are actually nonstationary, since they are bounded by definition; were several more decades added to the researcher's purview, the data might uniformly show stationary mean reversion. In short, political researchers may be too quick to find unit roots where none exist. On further investigation, Westerlund's (2007) error correction-based panel tests showed no evidence of cointegration. Moreover, using first-differences of slowchanging variables such as perceived corruption would inappropriately remove from the data the theoretical concept of interest: the effect of the level of perceived corruption, rather than the effect of small interannual changes. I have therefore avoided using a first-difference or error correction specification for the main model. In robustness tests, alternative estimation techniques and time lags are modeled to ensure the results are not unduly biased by such assumptions.

\section{Results and Analysis}

The results for nonmarket, market-based, and overall policy stringency are presented in Table 2. As hypothesized, greater perceptions of corruption are strongly associated with weaker national climate policies, when controlling for other relevant political and economic factors. Perceptions of corruption, energy-intensive manufacturing, and trade openness are all significantly correlated with the overall stringency of climate policies; at the same time, left-wing government ideology, corporatism, disproportional representation, per capita GDP, and the contribution of hydro and nuclear power to the electricity mix have a statistically nonsignificant effect on the strength of the climate policies modeled. Notwithstanding the standard caveats about the sensitivity of regression analyses to the choice of dependent variable, these null results are a notable departure from findings in previous qualitative and quantitative studies (Harrison and Sundstrom 2010; Lijphart 2012; Neumayer 2003; Scruggs 2003).

The negative effect of perceived corruption is notably somewhat greater for nonmarket climate policies, that is, emissions limits and regulations and public spending on renewable energy. There are plausible explanations for this finding. Perceptions of political corruption imply, first and foremost, distrust of politicians and government, but not necessarily distrust of markets. Nonmarket climate policies are state-centric and involve an enhanced regulatory role for government in the economy; they are therefore the kinds of climate policies most immediately affected by perceived corruption. This dynamic was apparent, for example, in the case of Solyndra in the US, a solar photovoltaic company

8. Multiple tests (Levin-Lin-Chu, Im-Pesaran-Shin, etc.) were used with up to three lags, including Pesaran's (2007) panel unit-root (CIPS) test, which can accommodate cross-section dependence and serially correlated errors. 
Table 2

Results for Climate Policy Stringency, 1990-2012

\begin{tabular}{lccc}
\hline & Nonmarket & Market-based & Overall \\
\hline Perceived corruption & -0.084 & -0.073 & -0.080 \\
& $(0.002)$ & $(0.002)$ & $(0.000)$ \\
Left government ideology & 0.002 & 0.006 & 0.002 \\
& $(0.695)$ & $(0.266)$ & $(0.575)$ \\
Corporatism & -0.164 & 0.172 & 0.026 \\
& $(0.413)$ & $(0.306)$ & $(0.856)$ \\
Disproportional representation & -0.006 & -0.010 & -0.008 \\
& $(0.604)$ & $(0.379)$ & $(0.363)$ \\
LOG GDP per capita (PPP, const. & 1.713 & -0.572 & 0.491 \\
int. dollar) & $(0.000)$ & $(0.223)$ & $(0.138)$ \\
Mining, manufacturing, and utilities & -0.022 & -0.028 & -0.030 \\
(value added, \% GDP) & $(0.225)$ & $(0.021)$ & $(0.007)$ \\
LOG Trade openness & -0.817 & -0.442 & -0.600 \\
& $(0.023)$ & $(0.142)$ & $(0.025)$ \\
Hydro and nuclear (\% of electricity) & -0.001 & 0.002 & 0.001 \\
& $(0.943)$ & $(0.712)$ & $(0.734)$ \\
Observations & 439 & 439 & 439 \\
$R^{2}$ & 0.700 & 0.447 & 0.679 \\
\hline
\end{tabular}

Note. Prais-Winsten regression with panel-corrected standard errors and AR(1) autocorrelation structure. Entries are unstandardized coefficients with $p$-values in parentheses. Political variables and the hydronuclear variable are lagged to $t-1$. Results for time-specific and country-specific fixed effects are omitted for brevity.

awarded a US\$ 535 million government loan that later declared bankruptcy; subsequently, many conservatives declaimed against government overreach, and there was widespread media discussion of the alleged inappropriateness of nonmarket attempts by government to "pick winners" (Levendusky 2013, 28-29). A similar dynamic is transpiring with the Trump administration's efforts to overturn the Clean Power Plan, a primarily nonmarket approach to climate policy involving emission limits on coal-fired power plants. An even more paradigmatic case is Spain, which, from 2005 to 2012, increased its levels of perceived corruption while public funding for renewable energy stagnated and ultimately declined. Democracies bogged down by perceptions of institutional corruption will be far less likely to pass stringent nonmarket climate policies.

The analysis further suggests that all of the political variables other than perceived corruption-that is, left-wing ideology, corporatism, and disproportional representation-appear to have a minimal, statistically nonsignificant 
impact on market-based policies, when controlling for economic factors. It is possible that the insignificant outcome for market-based policies is due to the aforementioned limitations of the carbon price data in the EPS index and the resultant low levels of cross-national variation (very few countries had stringent market-based policies during the time period covered; see Figure 2). Although market-based policies have proliferated over the past decade, they remain weak and underutilized, with carbon prices typically well below US $\$ 15$ per ton of $\mathrm{CO}_{2}$, and therefore largely ineffectual at inducing energy system transformation (World Bank et al. 2017). This may bias the results, or it may simply mean that market-based policy stringency is exceedingly hard to predict. Insofar as few countries have passed stringent carbon pricing and feed-in tariffs, valid explanations of their passage will depend heavily on case studies of outliers. In any case, the apparent insignificance of political factors generally considered relevant in determining market-based policy stringency should be reassessed in the future when economy-wide, emissions-weighted carbon price data become available and pricing policies have had a longer tenure to examine.

That being said, as Table 2 reveals, aside from perceptions of corruption, a greater contribution to GDP from mining, manufacturing, and utilities exerts a dominant negative impact on market-based climate policies. This finding is consistent with case study evidence. In Germany, for example, while there have consistently been relatively low levels of perceived corruption, native energyintensive industries (coal, metals, chemicals, etc.) have successfully lobbied to slow the pace of the country's Energiewende, which has privileged the preservation of a strong export-driven comparative advantage over rapid decarbonization. These priorities are reflected in the Bundestag's gradual amendments to weaken Germany's highly effectual (albeit costly) feed-in tariffs for renewable energy as well as the government's rejection of both a domestic carbon tax on coal and a carbon price floor in the EU ETS hitherto. While households have paid higher prices for electricity as a result of Germany's market-based climate policies, native manufacturing has been largely exempted. Similar ecological tax exemptions for energy-intensive, trade-exposed industries exist across OECD countries, highlighting the persistence of competitiveness concerns when crafting market-based climate policies (Botta and Koźluk 2014).

\section{Robustness Tests}

Several additional versions of the model were tested to determine whether the coefficients and standard errors changed significantly. An alternative model with a panel-specific AR(1) autocorrelation structure returned similar results, as did a model using the feasible generalized least squares (FGLS) estimator. In fact, both estimators markedly increased the coefficients and decreased the standard errors for political variables. However, Beck and Katz (1995) demonstrate that the FGLS estimator tends to understate sampling variability and overstate confidence in the findings of TSCS models. I therefore do not report the results 
of these additional tests; the more conservative panel-corrected standard errors reported in Table 2 should be taken as more reliable.

I have additionally tested the original model using the CPI (Transparency International 2017) to determine whether the results are unduly dependent on the BCI. This produced coefficients and standard errors that were very similar for all independent variables.

To determine whether outliers with higher levels of perceived corruption inordinately affected the results, an additional model that excluded the most extreme cases of Greece and Italy was tested. This lowered the estimated coefficient for perceived corruption by a very minimal amount (a few percentage points), while all of the findings remained robust to the excluded cases and the model retained its predictive strength. I also tested a model excluding Denmark, since it is a slight outlier on the dependent variable, but this also returned similar results.

As a final check, several models were tested using alternative time lags (between zero and three years). This did not fundamentally alter the results, except in the case of eliminating all time lags, which turned left-wing government ideology into a variable with a far greater, significant positive impact on overall and nonmarket climate policy stringency. This may be because the original model did not factor in the possibility that climate policies may be exceedingly vulnerable to regime change and might be among the first policies to be downgraded with the ascension of right-wing parties; under such conditions, even a short time lag of one year may downplay the positive effect of left-wing and green ideology on climate policy, since a left-wing government from the previous year would be expected to predict policies of a right-wing government in the present year. There is also the possibility that left-wing and green parties may rise to power partially because of already weak environmental policies, complicating interpretation of their causal impact on policy in analyses using correlated variables. Hence the results in the original model suggesting that left-wing parties exert a minimal, statistically nonsignificant effect on climate policy should be treated with caution. Case studies of the German Greens, for example, would certainly suggest that overly stern generalizations are inappropriate.

\section{Perceived Corruption: The Achilles' Heel of Climate Policy?}

The empirical analysis of climate policies in twenty industrialized democracies from 1990 to 2012 has provided several policy-relevant discoveries. Importantly, regression results vary somewhat when considering only market-based or nonmarket policies in turn.

Nonmarket climate policies are significantly weakened by public perceptions of institutional corruption, as predicted, when controlling for other relevant political and economic factors. A government perceived by citizens to be "mildly corrupt" but that transitions to "very clean" would strengthen its nonmarket climate policies by approximately the same considerable amount that 
China did from 1990 to 2012; put differently, boosting public confidence in government by that approximate amount would be associated with Poland strengthening its nonmarket policies to levels in Denmark, Greece strengthening its policies to levels in Sweden, or the Czech Republic becoming as environmentally stringent as the Netherlands. ${ }^{9}$ If the theory outlined herein is correct, the causal mechanisms work as follows: perceived corruption is a symptom of undue strategic or legislative influence that undermines government effectiveness on a range of policies, but the perception itself also weakens politicians' mandate to pass stringent climate policies by inflaming public distrust of politicians, distracting political discourse with short-term scandals, bolstering the strategic leverage of energy-intensive businesses opposed to regulatory agendas, and incentivizing policy makers to adopt a laissez-faire or tawdry approach. The practical inverse of perceived corruption is public trust in politicians. Efforts to strengthen nonmarket climate policies must, therefore, involve efforts to resuscitate public confidence in government more generally. Industries and businesses in whose pecuniary interest it is to slash environmental regulations or public funding for clean energy competitors may find it advantageous to propagate notions of elite political misbehavior and corruption, as many libertarian and "free enterprise" lobbies do routinely. Vice versa, it would be in the public's environmental interest if notions of political impartiality and administrative competence were propagated in places bogged down by popular views that politicians are partial, nonresponsive, and play a pernicious role in the economy. Undoubtedly, such recommendations may appear exceedingly difficult to actualize and therefore somewhat unhelpful in practical political terms. But it is certainly conceivable that nonmarket climate policies could be formulated and promoted in a more transparent and publicly visible way than has typically been the norm, with a proactive strategy of communicating the environmental and socioeconomic benefits of particular regulations to citizens. This may help minimize the "solution aversion" of citizens predisposed to doubt the benefits of greater state involvement in regulating the economy (Campbell and Kay 2014) and potentially reinforce perceptions of government responsiveness.

Market-based climate policies have also been strongly and robustly associated with perceptions of corruption, while other political variables, including left-wing government ideology, corporatist interest group arrangements, and the proportionality of electoral systems, have each had statistically nonsignificant effect. These latter null findings, as previously noted, represent a significant departure from previous studies. Importantly, the analysis herein has also shown that market-based policies, unlike nonmarket policies, have been highly

9. These comparisons are based on the coefficient of perceived corruption in the nonmarket TSCS analysis, which is multiplied by 30 (corresponding to a reasonable approximation of a shift from mild corruption to very low corruption among developed countries in both the BCI and CPI). The value is then translated into a change in the EPS index for the year 2012. Countryto-country comparisons should be used with caution, as the relationships are likely to change year to year. 
correlated with the economic size of native energy-intensive industries. Decreasing the economic contribution of native mining and manufacturing by 10 percent of GDP would be associated with strengthening market-based climate policies from levels in Poland to levels in the Netherlands, or from levels in Greece to those in Switzerland. However, as a final caveat and point of caution, it is important to note that no country, not even among the greenest, high-trust, low-corruption states, has managed to pass highly stringent market-based policies, particularly when one transforms nominal carbon prices into "real" prices that account for differentiated coverage of emissions as well as substantial exemptions and free allocations granted by governments to energy-intensive, tradeexposed industries (Dolphin et al. 2016; see also Table 3). Notwithstanding

\section{Table 3}

Industry Exemptions for Market-Based Policies in Selected Countries

\begin{tabular}{|c|c|c|}
\hline Country & Fully or partially exempted instrument & Sector or product \\
\hline Australia & Carbon pricing mechanism & $\begin{array}{l}\text { Emissions-intensive and trade-exposed } \\
\text { industries, households, small businesses, } \\
\text { agriculture }\end{array}$ \\
\hline Austria & Energy tax & $\begin{array}{l}\text { Coal and gas used for all nonheating } \\
\text { purposes }\end{array}$ \\
\hline Canada & Fuel taxes & $\begin{array}{l}\text { All or most manufacturing, oil and gas } \\
\text { extraction, and coal and metal mining }\end{array}$ \\
\hline Denmark & $\begin{array}{l}\mathrm{CO}_{2} \text {, coal, petrol, electricity, } \\
\text { and sulfur taxes }\end{array}$ & All or most manufacturing \\
\hline \multirow[t]{2}{*}{ France } & Vehicle $\mathrm{CO}_{2} \operatorname{tax}$ & All or most manufacturing \\
\hline & Natural gas tax & Oil, gas, chemicals \\
\hline Germany & Mineral oils tax & All or most manufacturing \\
\hline \multirow[t]{2}{*}{ Ireland } & Electricity, $\mathrm{CO}_{2}$ taxes & Chemicals, metals \\
\hline & $\mathrm{CO}_{2} \operatorname{tax}$ & Coal mining \\
\hline Italy & Electricity tax & All or most manufacturing \\
\hline Japan & Petroleum, coal tax & Iron and steel, coke, and cement \\
\hline Norway & $\mathrm{CO}_{2} \operatorname{tax}$ & Industrial processes \\
\hline Sweden & $\mathrm{CO}_{2}$, electricity, sulfur taxes & All or most manufacturing \\
\hline Switzerland & $\mathrm{CO}_{2}$ levy (with conditions) & Most manufacturing (with conditions) \\
\hline $\begin{array}{l}\text { United } \\
\text { Kingdom }\end{array}$ & Climate change levy & $\begin{array}{l}\text { Most manufacturing (with conditions) and } \\
\text { households }\end{array}$ \\
\hline
\end{tabular}

Note. Information on exemptions is from the OECD's Policy Instruments for the Environment (PINE) database. Note that some exemptions listed (e.g., some in Denmark, Norway, and Sweden) have more recently been partly eliminated, but they are included here because they were relevant during at least part of the time period covered (1990-2012). Exemptions are subject to change over time, and the list is not exhaustive, but the table represents a list of full or partial exemptions relevant to climate policy and is intended for illustrative purposes. 
this important caveat, it is clear that the only countries that currently levy a nominal carbon price above US\$ $40 / \mathrm{tCO}_{2}$-Sweden, Switzerland, Finland, and Norway-are all high trust and low corruption (World Bank et al. 2017). Hence, while high-trust and low-corruption sociopolitical environments are certainly not sufficient conditions for the high carbon prices recommended to achieve Paris aims (Stiglitz and Stern 2017), they might be "necessary" conditions in the absence of complementary measures, such as strategic carbon revenue allocation and a clear communication of the environmental benefits (Klenert et al. 2018). Far more research is needed to ascertain the policy design features, economic and institutional reforms, and communication strategies that could plausibly resuscitate political trust where it has been lost. In the absence of such efforts, perceptions of corruption may prove to be the Achilles' heel of climate policy.

Ryan Rafaty is an associate at the Institute for New Economic Thinking at the Oxford Martin School, University of Oxford, and a fellow at the Centre for Environment, Energy, and Natural Resource Governance, University of Cambridge. He completed his PhD in political science at University of Cambridge in 2017.

\section{References}

Andersen, Mikael Skou. 2004. Vikings and Virtues: A Decade of $\mathrm{CO}_{2}$ Taxation. Climate Policy 4 (1): 13-24.

Armingeon, Klaus, Christian Isler, Laura Knöpfel, David Weisstanner, and Sarah Engler. 2014. Comparative Political Data Set 1960-2013. Bern: Institute of Political Science, University of Bern.

Bättig, Michèle B., and Thomas Bernauer. 2009. National Institutions and Global Public Goods: Are Democracies More Cooperative in Climate Change Policy? International Organization 63 (2): 281-308.

Beck, Nathaniel, and Jonathan N. Katz. 1995. What to Do (and Not to Do) with TimeSeries Cross-Section Data. American Political Science Review 89 (3): 634-647.

Beck, Nathaniel, and Jonathan N. Katz. 2011. Modeling Dynamics in Time-Series-CrossSection Political Economy Data. Annual Review of Political Science 14: 331-352.

Bekkouche, Yasmine, and Julia Cagé. 2018. The Price of a Vote: Evidence from France, 1993-2014. Working Paper 68, Institute for New Economic Thinking.

Bernauer, Thomas, and Tobias Böhmelt. 2013. Are Economically "Kinder, Gentler Societies" Also Greener? Environmental Science and Technology 47 (21): 11993-12001.

Botta, Enrico, and Tomasz Koźluk. 2014. Measuring Environmental Policy Stringency in OECD Countries: A Composite Index Approach. Working Paper 1177, OECD Economic Department.

Buchan, Bruce, and Lisa Hill. 2014. An Intellectual History of Political Corruption. Basingstoke, UK: Palgrave Macmillan.

Campbell, Troy H., and Aaron C. Kay. 2014. Solution Aversion: On the Relation Between Ideology and Motivated Disbelief. Journal of Personality and Social Psychology 107 (5): 809.

Caney, Simon. 2010. Climate Change and the Duties of the Advantaged. Critical Review of International Social and Political Philosophy 13 (1): 203-228. 
Damania, Richard, Per G. Fredriksson, and John A. List. 2003. Trade Liberalization, Corruption, and Environmental Policy Formation: Theory and Evidence. Journal of Environmental Economics and Management 46 (3): 490-512.

Dolphin, Geoffroy, Michael Pollitt, and David Newbery. 2016. The Political Economy of Carbon Pricing: A Panel Analysis. Working Paper 16267, Working Paper in Economics 1663, University of Cambridge Energy Policy Research Group.

Dunn, John. 2014. Breaking Democracy's Spell. New Haven, CT: Yale University Press.

Eckersley, Robyn. 2013. Poles Apart? The Social Construction of Responsibility for Climate Change in Australia and Norway. Australian Journal of Politics and History 59 (3): 382-396.

Edelman, Richard. 2017. 2017 Edelman Trust Barometer: Global Report. Available at https:// www.slideshare.net/EdelmanInsights/2017-edelman-trust-barometer-global-results71035413, last accessed June 11, 2018.

Ferguson, Thomas. 1995. Golden Rule: The Investment Theory of Party Competition and the Logic of Money-Driven Political Systems. Chicago: University of Chicago Press.

Ferguson, Thomas, Paul Jorgensen, and Jie Chen. 2018. Industrial Structure and Party Competition in an Age of Hunger Games: Donald Trump and the 2016 Presidential Election. Working Paper 66, Institute for New Economic Thinking.

Fredriksson, Per G., and Muthukumara Mani. 2002. The Rule of Law and the Pattern of Environment Protection. Working Paper, International Monetary Fund.

Fredriksson, Per G., and Eric Neumayer. 2016. Corruption and Climate Change Policies: Do the Bad Old Days Matter? Environmental and Resource Economics 63 (2): 451-469.

Gallagher, Michael. 1991. Proportionality, Disproportionality and Electoral Systems. Electoral Studies 10 (1): 33-51.

Gilens, Martin, and Benjamin I. Page. 2014. Testing Theories of American Politics: Elites, Interest Groups, and Average Citizens. Perspectives on Politics 12 (3): 564-581.

Grubb, Michael, Jean-Charles Hourcade, and Karsten Neuhoff. 2014. Planetary Economics: Energy, Climate Change and the Three Domains of Sustainable Development. New York: Routledge.

Gupta, Sanjeev, Hamid Davoodi, and Rosa Alonso-Terme. 2002. Does Corruption Affect Income Inequality and Poverty? Economics of Governance 3 (1): 23-45.

Hammar, Henrik, and Sverker C. Jagers. 2006. Can Trust in Politicians Explain Individuals' Support for Climate Policy? The Case of $\mathrm{CO}_{2}$ Tax. Climate Policy 5 (6): 613-625.

Harrison, Kathryn, and Lisa McIntosh Sundstrom. 2010. Global Commons, Domestic Decisions: The Comparative Politics of Climate Change. Cambridge, MA: MIT Press.

Heidenheimer, Arnold J. 2002. Perspectives on the Perception of Corruption. In Political Corruption: Concepts and Contexts, edited by Arnold J. Heidenheimer and Michael Johnston. New Brunswick, NJ: Transaction.

Holmberg, Sören, and Bo Rothstein. 2011. Dying of Corruption. Health Economics, Policy, and Law 6 (4): 529-547.

International Energy Agency. 2017. Renewables Information: OECD Renewables Supply and Consumption, 1990-2015. Available by subscription at http://data.iea.org/payment/ products/100-renewables-information-2017-edition.aspx.

Jahn, Detlef. 2011. Conceptualizing Left and Right in Comparative Politics: Towards a Deductive Approach. Party Politics 17 (6): 745-765.

Jahn, Detlef. 2014. Changing of the Guard: Trends in Corporatist Arrangements in 42 Highly Industrialized Societies from 1960 to 2010. Socio-economic Review 14 (1): 47-71. 
Jahn, Detlef. 2016. The Politics of Environmental Performance: Institutions and Preferences in Industrialized Democracies. Cambridge: Cambridge University Press.

Jenkins, Jesse D. 2014. Political Economy Constraints on Carbon Pricing Policies: What Are the Implications for Economic Efficiency, Environmental Efficacy, and Climate Policy Design? Energy Policy 69: 467-477.

Klenert, David, Linus Mattauch, Emmanuel Combet, Ottmar Edenhofer, Cameron Hepburn, Ryan Rafaty, and Nicholas Stern. 2018. Making Carbon Pricing Work for Citizens. Nature Climate Change.

Lessig, Lawrence. 2011. Republic, Lost: How Money Corrupts Congress-and a Plan to Stop It. New York: Twelve Books, an imprint of Hachette Books.

Lessig, Lawrence. 2013. "Institutional Corruption" Defined. Journal of Law, Medicine, and Ethics 41 (3): 553-555.

Levendusky, Matthew. 2013. How Partisan Media Polarize America. Chicago: University of Chicago Press.

Lijphart, Arend. 2012. Patterns of Democracy: Government Forms and Performance in ThirtySix Countries. New Haven, CT: Yale University Press.

Mauro, Paolo. 1995. Corruption and Growth. Quarterly Journal of Economics 110 (3): 681-712.

Moosbrugger, Lorelei. 2012. The Vulnerability Thesis: Interest Group Influence and Institutional Design. New Haven, CT: Yale University Press.

Nachmany, Michael, Sam Fankhauser, Jana Davidová, Nick Kingsmill, Tucker Landesman, Hitomi Roppongi, Philip Schleifer, Joana Setzer, Amelia Sharman, C. Stolle Singleton, Jayaraj Sundaresan, and Terry Townshend. 2017. Global Trends in Climate Change Legislation and Litigation: 2017 Update. London: Grantham Research Institute for Climate Change and the Environment.

Neumayer, Eric. 2003. Are Left-Wing Party Strength and Corporatism Good for the Environment? Evidence from Panel Analysis of Air Pollution in OECD Countries. Ecological Economics 45 (2): 203-220.

Nye, Joseph S. 1967. Corruption and Political Development: A Cost-Benefit Analysis. American Political Science Review 61 (2): 417-427.

Pellegrini, Lorenzo, and Reyer Gerlagh. 2006. Corruption, Democracy, and Environmental Policy: An Empirical Contribution to the Debate. Journal of Environment and Development 15 (3): 332-354.

Persily, Nathaniel, and Kelli Lammie. 2004. Perceptions of Corruption and Campaign Finance: When Public Opinion Determines Constitutional Law. University of Pennsylvania Law Review 153: 119-180.

Pesaran, M. Hashem. 2007. A Simple Panel Unit Root Test in the Presence of CrossSection Dependence. Journal of Applied Econometrics 22 (2): 265-312.

Peters, John G., and Susan Welch. 1978. Political Corruption in America: A Search for Definitions and a Theory, or If Political Corruption Is in the Mainstream of American Politics Why Is It Not in the Mainstream of American Politics Research? American Political Science Review 72 (3): 974-984.

Rogelj, Joeri, Michel Den Elzen, Niklas Höhne, Taryn Fransen, Hanna Fekete, Harald Winkler, Roberto Schaeffer, Fu Sha, Keywan Riahi, and Malte Meinshausen. 2016. Paris Agreement Climate Proposals Need a Boost to Keep Warming Well Below $2^{\circ} \mathrm{C}$. Nature 534 (7609): 631-639.

Rootes, Christopher. 2014. A Referendum on the Carbon Tax? The 2013 Australian Election, the Greens, and the Environment. Environmental Politics 23 (1): 166-173. 
Rothstein, Bo, and Aiysha Varraich. 2017. Making Sense of Corruption. Cambridge: Cambridge University Press.

Runciman, David. 2017. How Climate Scepticism Turned into Something More Dangerous. Guardian, July 7.

Scruggs, Lyle. 2003. Sustaining Abundance: Environmental Performance in Industrial Democracies. Cambridge: Cambridge University Press.

Standaert, Samuel. 2015. Divining the Level of Corruption: A Bayesian State-Space Approach. Journal of Comparative Economics 43 (3): 782-803.

Steves, Franklin, and Alexander Teytelboym. 2013. Political Economy of Climate Change Policy. Working Paper 13-06, Smith School of Enterprise and the Environment, Oxford University.

Stiglitz, Joseph, and Nicholas Stern. 2017. Report of the High-Level Commission on Carbon Prices. Washington, DC: Carbon Pricing Leadership Coalition.

Torcal, Mariano. 2014. The Decline of Political Trust in Spain and Portugal: Economic Performance or Political Responsiveness? American Behavioral Scientist 58 (12): 1542-1567.

Transparency International. 2017. Corruption Perceptions Index 2016. Berlin: Transparency International, International Secretariat. Available at https://www.transparency.org/ whatwedo/publication/corruption_perceptions_index_2016, last accessed June 11, 2018.

United Nations Framework Convention on Climate Change. 2015. Adoption of the Paris Agreement, 21st Conference of the Parties. Paris: United Nations.

United Nations Statistics Division. 2017. National Accounts Main Aggregates Database. Available at https://unstats.un.org/unsd/snaama/introduction.asp, last accessed June 11, 2018.

Victor, David G., Keigo Akimoto, Yoichi Kaya, Mitsutsune Yamaguchi, Danny Cullenward, and Cameron Hepburn. 2017. Prove Paris Was More Than Paper Promises. Nature 548: 25-27.

Westerlund, Joakim. 2007. Testing for Error Correction in Panel Data. Oxford Bulletin of Economics and Statistics 69 (6): 709-748.

Winters, Jeffrey A., and Benjamin I. Page. 2009. Oligarchy in the United States? Perspectives on Politics 7 (4): 731-751.

World Bank. 2017. World Development Indicators. Washington, DC: World Bank.

World Bank, Vivid Economics, and Ecofys. 2017. State and Trends of Carbon Pricing 2017. Washington, DC: World Bank. 